\title{
Legal Settlement Policy in the Community of Sodong Ponorogo Village: A Comparison Between National Law and Alternative Disputed Resolution (ADR)
}

\author{
Arief Budiono $^{1}$; Aries Isnandar²; Alfalachu Indiantoro ${ }^{2}$ \\ ${ }^{1}$ Universitas Muhammadiyah Surakarta, Indonesia \\ ${ }^{2}$ Universitas Muhammadiyah Ponorogo, Indonesia
}

http://dx.doi.org/10.18415/ijmmu.v8i9.3059

\begin{abstract}
In this study, the author must focus on legal and social issues that interact with law at the regional (local), national, regional, and international levels. This is to determine the extent to which legislation meets philosophical, sociological, and juridical values. we know that Indonesia is a country that adheres to the European Continental legal system or Civil Law, actually this system came from the Netherlands which at that time colonized Indonesia for more than 350 years, at that time the Dutch laid the legal foundation "Civil Law" is the oldest legal system and most influential in the world. This legal system stems from the RomanGerman tradition. Around the 450th century BC, the Roman Empire made their first set of written rules called the "Twelve Tables of Rome". This Roman legal system spread to various parts of the world along with the expansion of the Roman Empire. This legal system was later codified by Emperor Justinus in the 6th century. The Corpus Juris Civilis was completed in 534 AD. When Europe began to have its own government, Roman law was used as the basis of the national laws of each country. Napoleon Bonaparte in France with its Napoleonic Code in 1804 and Germany with its Civil Code in 1896.
\end{abstract}

Keywords: Legal Settlement; Sodong Ponorogo Village; National Law; Disputed Resolution (ADR)

\section{Introduction}

In this study, the author must focus on legal and social issues that interact with law at the regional (local), national, regional, and international levels. This is to determine the extent to which legislation meets philosophical, sociological, and juridical values. we know that Indonesia is a country that adheres to the European Continental legal system or Civil Law, actually this system came from the Netherlands which at that time colonized Indonesia for more than 350 years, at that time the Dutch laid the legal foundation "Civil Law" is the oldest legal system and most influential in the world. This legal system stems from the RomanGerman tradition. Around the 450th century BC, the Roman Empire made their first set of written rules called the "Twelve Tables of Rome". This Roman legal system spread to various parts of the world along with the expansion of the Roman Empire. This legal system was later codified by Emperor Justinus in the 6th century. The Corpus Juris Civilis was completed in 534 AD. When Europe began to have its own government, Roman law was used as the basis of the national laws of each country. Napoleon Bonaparte in France with its Napoleonic Code in 1804 and Germany with its Civil Code in 1896. ${ }^{1}$

${ }^{1}$ Dhea Meirani Nugroho, Perbedaan Civil Law Dan Common Law. Https://Dheameiranin.Wordpress.Com/Silabus/PengantarHukum-Indonesia/Perbedaan-Civil-Law-Dan-Common-Law/ ( diakses pada april 2017) 
Actually, if we understand that in the archipelago during the Sriwijaya kingdom, there was already a legal order, but it didn't have a clear concept because the kingdoms that developed in Indonesia from the Sriwijaya kingdom to Majapahit had an authority that was fragmented in accordance with their respective desired authorities. . For example, the Srivijaya kingdom: Structurally, the Srivijaya King ruled directly over the entire territory (conquered). In some conquered areas, a deputy king was also placed as regional ruler. This vice king usually still descended from the reigning king. Then it makes sense if also found an inscription containing a curse for family members.

kingdom. The purpose of this curse is to show the strong attitude of the ruling king, as well as an attitude of the king who does not want too much freedom of action for regional authorities (Marwati \& Nugroho, 1993:72). This kind of attitude is very necessary to maintain the existence of the power of a king as the highest ruler in Sriwijaya.that may happen to regional rulers, even though the rulers are still family or descendants of the king.

Control of power is also carried out through military force. As stated in the Kedukan Bukit Inscription, Dapunta Hyang Sri Jayanaga led an army of 20,000 soldiers to conquer the area /Ma-ta-dja /(?), an area that is still being debated by experts, including Coedes and N.J. Chrome (Slamet,2006:137). The number of 20,000 soldiers in the 7th century of course will increase many times when Srivijaya is able to expand the conquered area to Southeast Asia. Regional control can also be done by deploying troops if it is known that there are regional rulers who are not subject to the King of Srivijaya. ${ }^{2}$

After the era of the kingdom ended at the time of the collapse of the Majapahit kingdom, there was no regeneration that could continue the superiority that had been owned by the kingdoms throughout the archipelago which in this case became the Unitary State of the Republic of Indonesia. Indeed, there are still kingdoms on the island of Java, especially those that are still growing and still have a fairly strong government at that time, for example the Mataram kingdom which during the colonial period was still taken into account by the Dutch East Indies government. Of all the processes that took place in the archipelago at that time, there was no one strongest royal government besides the Sriwijaya kingdom and the Mojopahit kingdom at that time, the Mataram kingdom because there was not only a clear system of government and almost all systems of government that were not limited which until now still exist. remains even though it has begun to be abandoned by the progress of the times, as is the case in DI Yogyakarta.

The Dutch, who colonized Indonesia at that time, were admitted to have laid a clearer legal basis, namely the continental European system or civil law, meaning that it was written, codified, promulgated, and enforced, even though at that time the Dutch were colonizers, the implementation of the Dutch law could not be rejected by the people. or the natives are forced to obey it to follow it so that the implementation of this Dutch law is very subjective.

In this paper, the author tries to re-explore that from several problem resolutions that occurred in certain areas, especially Sodong Village, Sampung District, Ponorogo Regency, customary law can still be used for alternative solutions, especially criminal cases. The Criminal Code for certain matters can be set aside in order to legalize customary rules that develop in the area on condition that they do not violate existing legal principles if we think that the common law legal system still respects customary law and developments that have occurred. Positivism in Indonesia cannot be carried out purely and consistently because the judicial system, both the European continental system and the common law system both respect customary law and developments that occur, an example of a judiciary in Indonesia should not reject a lawsuit that is still valid. uk on the judiciary means that even if there is no legal basis, it must explore developments that occur not only based on jurisprudence, especially the common law legal system, in addition to relying on jurisprudence, guided by local customary law and must explore developments that occur even though there are many other sides as well. the difference but the principle of extracting the law is almost the same. Departing from this, the author tries to correlate the customary law of the continental

${ }^{2}$ Septianputrapratama,Sejarah Kerajaan Sriwijaya. http://septianputrapratama-tp-unbara.blogspot.co.id/2012/11/sistempemerintahan-kerajaan-sriwijaya.html (diakses pada april 2017)

Legal Settlement Policy in the Community of Sodong Ponorogo Village: A Comparison Between National Law and Alternative Disputed Resolution (ADR) 
system and the common law system, especially in Law no. 6 of 2014 concerning villages, mandates that Article 1 in this Law is meant by: 1. Villages are villages and customary villages or what is called by another name, hereinafter referred to as Village, is a legal community unit that has territorial boundaries that are authorized to regulate and manage government affairs, the interests of the local community based on community initiatives, rights of origin, and/or traditional rights that are recognized and respected in the government system of the Unitary State of the Republic of Indonesia. And the Customary Village Regulation Article 110 Customary Village Regulations are adjusted to the customary law and customary norms that apply in the Traditional Village as long as they do not conflict with the provisions of the legislation.

The author tries to observe the Sodong Hamlet, which is in the village of Bracelet, Sampung District, Ponorogo Regency, a remote village located in this hamlet that cannot be reached from the center of the Gelang Kulon village. I had to turn past Kunti village first to get to this village. From the start, the head of the village of Gelang Kulon gave a message to me to be careful when riding a motorbike there because the road was still rocky and up and down. He also advised not to go home after sunset because the road was very dark and there were no lights. The head of the hamlet in Sodong hamlet is a Buddhist community, about $40 \%$ of Sodong's population is Buddhist and 60\% Muslim. However, the head of the hamlet is of the opinion that the people of this hamlet live in harmony. It's a very interesting story but lately it has started to decrease a lot for Buddhists. The problem is not about religion or the community in Sodong Hamlet, Bracelet Village, Sampung District, Ponorogo Regency, but how the villagers interact to create a peaceful and harmonious village with agreed commitments, this is of course after the author communicates with Buddhist community leaders, including Islamic leaders, the community mingles like relatives and it doesn't appear that actually differences in beliefs are not at all an obstacle in social life, meaning that they really flow in their lives so that the socio-juridical process that occurs arises because it is needed by the community itself., because to meet the needs of situations and conditions that occur and naturally the community is aware or not aware of the discovery / exploration of the desired rules excavated from habits that have occurred such as customs that arise and develop in the area.

"The study of the sociology of law on the decline in public trust in the law and law enforcement officers in North Sulawesi "by Tonny Rompis in 2015 discusses the relationship between law enforcement and the level of public trust and how efforts can be taken so that people can have confidence in law enforcement in the province of North Sulawesi.

The study of the sociology of law on the application of the principles of restorative justice in the settlement of criminal cases written by Prof. Dr. Musakkir, S.H., M.H., law enforcers do not abuse restorative justice for their own deviant interests. Law enforcers may not ask the defendant and his family for the assistance that has been given. It must be purely for the sake of justice and the benefit of society. So it must be really selective and carried out appropriately according to the principles of the law itself.

From the description above, the writer believes that this paper has never been studied by other authors, so that the author continues this paper with the idea and idea of a rule from a juridical sociological process that occurs in society and is integrated into the rules as an alternative solution.

Based on the ideas and ideas as well as the study that the author did, it can be formulated:

1. What are the patterns of settlement of criminal cases through Alternative Dispute Resolution (ADR)?

2. How is the concept of juridical sociological agreement related to the concept of forgiveness in society related to criminal cases and sanctions?.

3. What is the validity of the settlement of cases through ADR? 


\section{Research Method}

This research is a legal research with a normative juridical method with an anthropological approach. This research is a descriptive study that describes the people of Sadong village. This research is also a comparative study that compares the validity of the settlement of cases between ADR and state law.

\section{Positivism and Traditional Law}

\section{A. Civil Law System and Its Development}

In the era of Indonesia's independence on August 17, 1945, like it or not, Indonesia must not experience a legal vacuum so that with the strategy of Article 2 of the transitional rules of the 1945 Constitution, Indonesia can incorporate Dutch legal rules that are enforced such as HIR (now the Code of Procedural Law). Criminal Law), Wetbook Van Strafrecht (Book of Criminal Law), Wetbook van Kophandle (Book of Commercial Law, Bergelijk Werbook (Book of Civil Law) and so on from all this journey, Indonesia currently adheres to positivistic law that Along the way, it must have its strengths and weaknesses.

Positivism and its Development. The 19th century marked the emergence of the positivism movement in society and in the field of law, positivism in the legal field is known as juridical positivism. This century received a legacy of ideas from previous periods that were idealistic, such as the laws of nature. At the same time, developments and changes in society that occurred in the 19th century have created a spirit and a critical attitude towards the problems faced. The views and attitudes that are critical of the laws of nature have produced results that undermine the existence of these natural laws. By critical thinking it is shown, but the law has no basis, or is the result of false reasoning. ${ }^{3}$

This flow (positivism) is known for its two well-known sub-schools, namely ${ }^{4}$ :

1. The analytical positive law school, the foundation of which is John Austin.

2. The school of pure positive law, pioneered by Hans Kelsen.

The analytical positive flow of law defines the law as a command of the lawgiver (an order from the legislator or ruler), which is an order from those who hold the highest power or who hold sovereignty. Law is considered as a logical, fixed, and closed logical system. Law is strictly separated from morals, so from matters relating to justice, and is not based on good-bad judgments or judgments.

The flow of positivism that was born about 2 centuries ago cannot be separated from the political context that characterizes the presence of a modern state, namely the political factor of liberalism. The focus of liberal thought is on individual freedom, so it is very logical if positivism which historically was born in an atmosphere of liberalism was not designed to think about and provide broad justice for society.

The legal system, in the positivist paradigm, is not established to provide justice for the community, but only to protect individual independence. The positivism paradigm holds that, for the sake of certainty, justice and benefit may be sacrificed. ${ }^{5}$ The law as promulgated, established, must always be separated from the law that should be created, which is desired. This is what we now often accept as giving meaning to positivism. Austin (1790-1859) a major positivism, maintains that the only source of law is the supreme power in a state. Other sources are referred to as lesser sources. Austin further states that law is an order from a sovereign political power in a country. Another positivism was Geremy Bentham (1748-1832) an ardent fighter for the codification of English law. ${ }^{6}$

${ }^{3}$ Satjipto Rahardjo. 1991. Ilmu Hukum. Bandung: Citra Aditya Bakti. Hal. 267

${ }^{4}$ Lili Rasyidi. 1993. Dasar-dasar Filsafat Hukum. Bandung: Citra Aditya Bakti. Hal. 42

${ }^{5}$ Achmad Ali. 2002. Keterpurukan Hukum di Indonesia. Jakarta: Ghalia Indonesia. Hal 40-410

${ }^{6}$ Satjipto Rahardjo. op. cit. Hal 227

Legal Settlement Policy in the Community of Sodong Ponorogo Village: A Comparison Between National Law and Alternative Disputed Resolution (ADR) 
The mind of positivism mainly develops in a stable society. But what is very interesting is that neither Austin nor Bentham expressed their thoughts on positivism in the stable state of society as it was then. Bentham and Austin argue that there must first be complete clarity about the law as it is. The positivism of both is based on their rejection of naturalism and their love of order and accuracy. ${ }^{7}$

The study of legal positivism in Indonesia is very important apart from looking at the debates rooted in the choice of which legal school (theory) is good or not appropriate to be applied in Indonesia. This is at least due to the view that under the influence of the positivism paradigm, legal actors place themselves with a positivist and rule-based legalistic way of thinking and understanding law (rule bound) so that they are unable to capture the truth, because they do not want to see or admit it. that matter. In positivist legalism, law is only considered as a complex regulatory institution which has been reduced to something simple, linear, mechanistic, and deterministic, especially for the benefit of the profession. In the context of Indonesian law, such legal doctrines and teachings are still dominant, including Schuyt's "legism" category. This is because "legism" sees the legal world from a mere statutory telescope and then judges the events that occur. ${ }^{8}$

To obtain an objectivity towards legal positivism in Indonesia, of course, it cannot be separated from the history and essence of legal positivism at the beginning, that before the 18th century the idea regarding legal positivism already existed, but this thought only strengthened after the birth of modern countries. On the other hand, legal positivism is also inseparable from the influence of the development of positivism (science) and at the same time shows its difference from natural law thinking, where natural law is preoccupied with problems of validating man-made laws, while in legal positivism activities are instead reduced to concrete problems. Through positivism, law is viewed from the point of view of juridical positivism in an absolute sense and legal positivism is often seen as a legal school that separates law from morals and religion, between das solen and das sein. Not even a little discussion of legal positivism has come to the conclusion that from a positivist perspective there is no other law except the command of the ruler (law is command from the lawgivers), the law is identical to the law. Legal Positivism places great emphasis on law as a mechanistic and deterministic regulatory institution.

That the emergence of the positivism movement influenced many thoughts in various fields of science about human life. ${ }^{9}$ Positivism as a school of philosophy that states the natural sciences as the only true source of knowledge and rejects activities related to metaphysics. There is no speculation, everything is based on empirical data. In fact, this school rejects the existence of theoretical speculation as a means of obtaining knowledge (as advocated by idealism, especially classical German idealism).

In principle, legal positivism adheres to the continental European system, meaning that it is written, codified and legislated so that it seems that legal actors / legal apparatus seem to be the spokespersons for laws which in principle apply all the rules that have been promulgated. This can be justified or still needs to be reviewed because in substance legal positivism only adopts laws originating from the Netherlands. This means that the legal provisions from the Netherlands are translated into Indonesian in accordance with the conditions that occurred at that time until now.

\section{B. Customary Law and Its Development}

Actually, the original law of the Indonesian nation emerged from customary law, for example Minangkabau adat is the rules and laws or customary law that applies in the social life of the Minangkabau community, especially those who live in the Minang realm or West Sumatra. To a certain extent, Minangkabau adat is also used and applies to Minang people who are overseas outside the Minangkabau region. Adat is the basis for the power of the Kings and Penghulu, and is used in carrying out daily

\footnotetext{
${ }^{7}$ Satjipto Rahardjo. loc. cit. Hal 227

${ }^{8}$ Khudzaifah Dimyati, Teorisasi Hukum: Studi tentang Perkembangan Pemikiran Hukum di Indonesia 1945-1990, Cetakan keempat (Surakarta: MuhammadiyahUniversity Press, 2005), hal. 60-1

${ }^{9}$ Khudzaifah Dimyati. Ibid. hal. 60-1

Legal Settlement Policy in the Community of Sodong Ponorogo Village: A Comparison Between National Law and Alternative Disputed Resolution (ADR) 
government. All laws and regulations are called Adat, and the basis is a tradition inherited from generation to generation and Islamic law that has been embraced by the Minangkabau community. A King or Penghulu holds power because of heredity, and that power becomes valid because it is supported by the ulama who hold religious authority in society. From this idea emerged the adage Adat basandi syarak; The syarak of the Book of Allah. After the arrival of European colonialists, the customary law area was limited only to the arrangement of the position of the Penghulu, power over the Ulayat Land, inheritance regulations, marriage, and customs only. Legal, security and territorial powers were taken over by the colonial government. This situation continued until the time of independence. After the enactment of the 1999 Regional Autonomy Law and the Return to Nagari movement, Minang Adat got a better place and was included as one of the foundations of Nagari government, Regency Regional Government, and Provincial Government, after the 1945 Constitution. ${ }^{10}$

Balinese Cockfighting or known as Tajen is a tradition of cockfighting competition using knives in the Hindu custom of the island of the gods. Bali is a famous island in Indonesia, even the fame of this island of the gods reaches the whole world. One of the Balinese traditions that is quite popular besides the Kecak dance, leak and so on is the Cockfighting tradition or known as Tajen Bali. "Tajen" is a Balinese language which means cockfighting, namely; the procession pitted two roosters until one of the chickens ran away / gave up losing / died.

The history and origin of the tradition of fighting cocks in Bali is said to have originated from the Majapahit era, formerly a hobby of the ancient Javanese kings. But there is another version which says that Tajen in Bali stems from a shift in the culture and tradition of Tabuh Rah, namely the religious rituals of Balinese Hindus. As in other areas in Bali itself, there are types of chickens that are most often used for this Balinese cockfighting event. The chicken is a parrot type chicken which is called a mixed breed of various types of chickens such as Filipino chickens and native chickens. ${ }^{11}$

The problem now is that in positive law in Indonesia, the cockfighting that occurs in Balinese custom is closely related to gambling. This is in material law (KUHP) if it is applied, it should be subject to action in accordance with the provisions of the elements related to Article 303 of the Criminal Code. If not with gambling, then ethically cockfighting is a tradition, legally and religious norms are not appropriate to be made a tradition.

Sigajang Laleng Lipa, is a tradition that is followed by the men of the Bugis tribe, Makassar when solving problems. The tradition is in the form of a fight between men, but carried out in a sarong. This tradition was carried out during the time of the Bugis kingdom, and this was the last resort to resolve an unresolved customary problem. Even though lives are at stake, the Makassar Bugis still have special ways to solve problems wisely. As in the Bugis Makassar proverb which roughly means "when the badik has come out of the sheath, don't slip it on the waist before it hits the opponent's body". The meaning of the philosophy is to remind that a problem is always sought for the best solution without badik. This is usually done through deliberation involving the two problematic parties and the customary council.

If an agreement is not reached in the deliberation, eating face to face or fighting is the last option. However, this is also done in its own way. The Bugis Makassar face to face with an opponent who is resolved by "assigajangeng" (baku stabbing) is the last way, carried out in one sarong. Face to face, each armed with a badik/kawali (traditional weapon of the Bugis Makassar community) with only a single ring of gloves. Place, time and witnesses are determined. Usually this is difficult to avoid when the problem involves "siri" (shame, self-esteem). The values of the Sigajang Laleng Lipa ritual (one sarong duel), which is interpreted as a sarong as a symbol of unity and togetherness of the Bugis Makassar community, being in one sarong means that we are in one common habitat. So the sarong that binds us is not a chainlike bond that entangles itself, but becomes a bond of togetherness between humans.

\footnotetext{
${ }^{10}$ Darwis Thaib glr. Dt. Sidi Bandaro, Seluk Beluk Adat Minangkabau, N.V. Nusantara Bukittinggi -- Djakarta

${ }^{11}$ Acara Adat Keramat Bali Dan Sabung Ayam Bali, http://ayamtempur.com/adat-keramat-bali-dan-sabung-ayam-bali/ , di terbitkan pada 8 Januari 2017 (diakses pada 10 april 2017)
} 
Along with the progress of education, this kind of ritual has been abandoned by the Bugis Makassar community, but now this Sigajang tradition has been preserved as the ancestral cultural heritage of South Sulawesi, which is performed on stage. ${ }^{12}$

As stated by Prof. Aidul Fitriciada Azhari, S.H., M. Hum. in his book Reconstruction of state traditions in the 1945 Constitution that in the legal context, as Popper stated, tradition has a parallel function with legislation or the formation of law to provide order to society. There is no contradiction between tradition and legislation regarding such a function of order. On that basis, several traditions have developed into habits that are obeyed by a community as legal norms called customary law or adat. Likewise, several positive legal norms in modern countries which naturally have a rational basis can be formed based on tradition because both have the same social function to establish and maintain social order. ${ }^{13}$

\section{Juridical Sociology and Its Development}

The term Customary Law Community is a translation of the term rechtsgemeenchappen. This term was first found in Mr. B. Ter Haar Bzn. entitled Beginselen en Stelsel van Hat Adat Recht"e. In the Construction of Customary Law Communities in Article 18B of the Indonesian Constitution, Sabardi 171 further developments from legal studies, the use of the term Indigenous Law Community is often found when legal experts discuss the issue of Natural Resources (hereinafter abbreviated as SDA). Where in this legal study of natural resources, there are many discussions between the interests and rules of the Indigenous Law Community versus the State. In fact, in various laws and regulations concerning natural resources produced by the State, the conditions for recognition and respect for Indigenous Law Communities have been regulated. The most recent regulation is the second amendment to the 1945 Constitution of the Republic of Indonesia, specifically the provisions of Article 18 B Paragraph 2. Regulations concerning Indigenous Peoples are placed as part of the regulations concerning Regional Government. The term used in the Article is 'Indigenous Law Community units'. Before the term Customary Law Community was included in the Amendment to the 1945 Constitution of the Republic of Indonesia, various laws and regulations had already mentioned it. For example, in Law Number 5 of 1960 concerning Basic Regulations on Agrarian Principles, specifically in Article 2 (4) which stipulates that "The above-mentioned State's control rights can be exercised to autonomous regions and customary law communities, just necessary and does not conflict with national interests, according to the provisions of Government Regulations". Then also in Law no. 41 of 1999 concerning Forestry, Article 4 Paragraph (3) which stipulates that "The control of forests by the State shall continue to pay attention to the rights of indigenous peoples, as long as they exist and are recognized, and do not conflict with national interests". However, the two laws mentioned above do not explain in detail the concept of the 'customary law community'. In Law no. 41 of 1999 even stated that (customary law communities) "as long as the fact still exists", "its existence is acknowledged". This causes the potential for multiple interpretations and becomes fertile ground for conflicting norms in the practice of constitutional life of the Republic of Indonesia, especially in the context of the relationship between power, recognition, and respect. This situation causes the recognition and respect that is intended for the Indigenous Law Community cannot be implemented. The potential for multiple interpretations, for example, can be seen from the aspect of 'who is included in the Customary Law Community'. This has led to a debate about the personal identity of individuals who are in the Customary Law Community group, relating to the recognition of the relationship between the group (the Customary Law Community) and the individual as a member of an Indigenous Law Community.

Moreover, the confusion in the use of the term also adds to the ambiguity of what is meant by 'customary law community'. Article 18B Paragraph (2) of the 1945 Constitution of the Republic of Indonesia uses the term Customary Law Community Units. Various other regulations in the field of natural resource law use different terms, such as: Indigenous Peoples, Indigenous Law Communities and Traditional Communities. The problem is, this diversity does not only involve terms, but also has an impact

\footnotetext{
${ }^{12}$ Bangir, Bertarung Dalam Sarung, Tradisi Lelaki Bugis Selesaikan Masalah, https://planet.merdeka.com/sejarah/bertarungdalam-sarung-tradisi-lelaki-bugis-selesaikan-masalah.html.

15 November 2016 ( diakses pada 10 April 2017)

${ }^{13}$ Prof. Aidul Fitriciada Azhari, S.H., M.Hum. Rekonstruksi tradisi bernegara dalam UUD 1945. 2014. Hal. 10-11
} 
on the diversity of meanings on the institutional boundaries of the Indigenous Law Community. In the applicable realm of normative provisions, a firm translation is needed, both regarding the meaning, types and forms of Indigenous Law Communities, so that such recognition and protection can be carried out by the State. Recognition and protection carried out by the State against Indigenous Law Communities, can be realized if there is a legal basis in the form of statutory regulations, namely the Law on Indigenous Law Communities.

The definition of recognition and protection has actually also been regulated in Article 4 (1) of the Law of the Republic of Indonesia. No. 41 of 1999 concerning Forestry. In the article it is seen that all forests, including the wealth in them, are controlled by the state and used for the greatest prosperity of the people. What needs to be kept in mind so that it becomes clear is a statement concerning "for the greatest prosperity of the people". The word people included in the statement should be defined in the explanation section so that it is clear what segment the people are in, by what level of power? This is still not clear in this law. However, what is certain is that there must be an understanding of where natural resources must be utilized, must be maintained, maintained, and the stakeholders (community and state) involved in the use, management and maintenance of them must have mutual respect in the form of actions. These things will become the contents of the Act in order to be able to reach the "greatest prosperity of the people".

Regarding the term respect, in constitutional theory it is the same as recognizing sovereignty. This means that by analogy it has the same position as "recognizing and respecting special regions and special regions". In this case, Pan Mohamad Faiz gives the meaning as:

a. All forms of utilization (earth and water) and the results obtained (natural wealth), must significantly increase the prosperity and welfare of the community.

b. Protect and guarantee all the rights of the people contained in or on the earth, water and certain natural resources that can be produced directly or enjoyed directly by the people.

c. Prevent all actions from any party that will cause the people to not have the opportunity or will lose their rights to enjoy natural resources.

The three obligations above explain the guarantees for the purpose of "respect" given by the state to customary law communities for natural resources while at the same time providing an understanding that in these tenure rights, the state only carries out management (bestuursdaad) and management (beheersdaad), does not act as owner ( eigensdaad). 6 If we take a closer look at the provisions of Article 5 of Law No. 41/1999 on Forestry, the term Customary Law Community has not yet received a clear understanding. Furthermore, several laws and regulations in order to explain what is meant by Indigenous Law Community, include the provisions of Article 18B of the Constitution of the Republic of Indonesia, as the original editor. As a result, there is no statutory regulation that contains an adequate explanation of what a Customary Law Community is. Thus, the normative provisions regarding what is meant by customary law community units are not yet clear, especially regarding the requirements for their recognition to be able to fulfill the requirements, "as long as they are still alive and in accordance with community development and the principles of the Unitary State of the Republic of Indonesia which are regulated by law.

The main purpose of this paper is to find the boundaries of the Indigenous Law Community. Then to find out which state institutions can provide protection to the Indigenous Law Community. Finally, to find out the form of state recognition and respect for Indigenous Law Communities.

There are several benefits that can be obtained from this research. First, by knowing the boundaries of the surviving Indigenous Law Communities and in accordance with the laws and regulations, these limits can be used as a guideline to determine the recognition, protection and respect for Indigenous Law Communities. Second, this research is a normative research, where it is hoped that the results of this research can contribute to the development of philosophical legal studies, and also to contribute to the material of thought regarding the principles and concepts of the Customary Law community. 
From the study that the author did, even in the village of Sodong, Sampung sub-district, Ponorogo district, there are communities that do maintain local customs related to the socio-juridical process in the village so that there are applicable legal provisions agreed upon by the local community, especially those that the authors highlight about criminal acts that occurred. in the village so that the community overrides the state rules contained in the Criminal Code or other laws related to the case. ${ }^{14}$

The Anglo Saxon legal system is essentially rooted in:

a. Custom

Is the oldest source of law, because it was born from and stems from some Roman law, this custom grew and developed from the customs of the Anglo Saxon tribes who lived in the Middle Ages. In the 14th century, custom law will give birth to common law and then replaced by precedent

b. Legislation

Means laws that are formed through parliament. Such laws are called statutes. Prior to the 15th century, legislation was not a source of law in England, because at that time laws were issued by the king and the Grand Council (consisting of prominent aristocrats and city rulers, and around the 14th century an overhaul was carried out which became known as the parliament.

c. Case-Law

As a source of law, especially in the UK, it is the most important characteristic. All customary law that develops in society does not go through parliament, but is carried out by judges, so it is known as judge made law, every judge's decision is a precedent for future judges so that the precedent doctrine is born until now. ${ }^{15}$

\section{Bibliography}

A, Latif Farikun, "Pengakuan Hak Masyarakat Hukum Adat Atas Sumber Daya Alam Dalam Politik Hukum Nasional”, Disertasi Universitas Brawijaya, 2007.

Achmad Ali. 2002. Keterpurukan Hukum Di Indonesia. Jakarta: Ghalia Indonesia

Acara Adat Keramat Bali Dan Sabung Ayam Bali, Http://Ayamtempur.Com/Adat-Keramat-Bali-DanSabung-Ayam-Bali/, Di Terbitkan Pada 8 Januari 2017 (Diakses Pada 10 April 2017)

Azahari. Aidul Fitriciada, Rekonstruksi Tradisi Bernegara Dalam Uud 1945, 2014, Yogyakarta: Genta Publishing

Bangir, Bertarung Dalam Sarung, Tradisi Lelaki Bugis Selesaikan Masalah, Https://Planet.Merdeka.Com/Sejarah/Bertarung-Dalam-Sarung-Tradisi-Lelaki-Bugis-SelesaikanMasalah.Html. 15 November 2016 ( Diakses Pada 10 April 2017)

Dardji Darmo Dihardjo Dan Sidarta. 2001. Pokok-Pokok Filsafat Hukum. Jakarta: Gramedia Pustaka Utama

Darwis Thaib Glr. Dt. Sidi Bandaro, Seluk Beluk Adat Minangkabau, N.V. Nusantara Bukittinggi Djakarta

Dhea Meirani Nugroho, Perbedaan Civil Law Dan Common Law. Https://Dheameiranin.Wordpress.Com/Silabus/Pengantar-Hukum-Indonesia/Perbedaan-Civil-LawDan-Common-Law/ ( Diakses Pada April 2017)

\footnotetext{
${ }^{14}$ Sistem Hukum Anglo Saxon dan Sistem hukum Eropa Kontinental http://rizalwirahadi.blogspot.co.id/2013/02/sistem-hukum-anglo-saxon-dan-sistem.html,16 Februari 2013(diakses pada april 2017) ${ }^{15}$ Ibid., hal 1

Legal Settlement Policy in the Community of Sodong Ponorogo Village: A Comparison Between National Law and Alternative Disputed Resolution (ADR) 
LG.Saraswati Dkk. "Hak Azazi Manusia, Teori, Hukum, Kasus", Depertemen Filasafat, Fakultas Pengetahuan Budaya UI, 2006.

Lili Rasyidi. 1993. Dasar-Dasar Filsafat Hukum. Bandung: Citra Aditya Bakti.

Mr. B. Ter Haar Bzn Diterjemahkan K. Ng. Soebakti Poesponoto, "Asas-Asas Dan Susunan Hukum Adat (Beginselen En Stelsel Van Hat Adat Recht)", Cetakan Kesembilan Belas, (Jakarta: PT.Pradnya Paramita,1987).

Pan Mohamad Faiz, Penafsiran Konsep Penguasaan Negara Berdasarkan Pasal 33 UUD 45 Dan Putusan Mahkamah Konstitusi, "Jurnal Hukum", Volume 9, No. 2, Th. 2005.

Prof. Aidul Fitriciada Azhari, S.H., M.Hum. Rekonstruksi Tradisi Bernegara Dalam UUD 1945. 2014.

Purnadi Purbacaraka. 1997. Penegakan Hukum Dalam Mensukseskan Pembangunan. Bandung: Alumni

Theo Huijbers. 1995. Filsafat Hukum. Yogyakarta: Kanisius

Tri Rama K, “Kamus Lengkap Bahasa Indonesia”, (Surabaya: Karya Agung, 2000).

Theo Huijbers. 1990. Filsafat Hukum Dalam Lintasan Sejarah.. Yogyakarta: Kanisius

Satjipto Rahardjo. 1991. Ilmu Hukum. Bandung: Citra Aditya Bakti

Lili Rasyidi. 1993. Dasar-Dasar Filsafat Hukum. Bandung: Citra Aditya Bakti

Khudzaifah Dimyati, Teorisasi Hukum: Studi Tentang Perkembangan Pemikiran Hukum Di Indonesia 1945-1990, Cetakan Keempat (Surakarta: Muhammadiyahuniversity Press, 2005),

Satjipto Rahardjo. 1991. Ilmu Hukum. Bandung: Citra Aditya Bakti.

Septianputrapratama,Sejarah Kerajaan Sriwijaya. Http:/Septianputrapratama-TpUnbara.Blogspot.Co.Id/2012/11/Sistem-Pemerintahan-Kerajaan-Sriwijaya.Html (Diakses Pada April 2017)

Sistem Hukum Anglo Saxon DanSistem Hukum Eropa Kontinental.Http://Rizalwirahadi.Blogspot.Co.Id/2013/02/Sistem-Hukum-Anglo-Saxon-DanSistem.Html, 16 Februari 2013 ( Diakses Pada April 2017)

\section{Copyrights}

Copyright for this article is retained by the author(s), with first publication rights granted to the journal.

This is an open-access article distributed under the terms and conditions of the Creative Commons Attribution license (http://creativecommons.org/licenses/by/4.0/). 